\title{
Strategic Consensus Between Functions and the Role of Supply Chain Technology as Moderator
}

\author{
Titik Kusmantini1(iD), Tulus Haryono2 (iD), Wisnu Untoro² ${ }^{2}$, Ahmad Ikhwan Setiawan² (iD \\ ${ }^{1}$ Faculty of Economics and Business, Universitas Pembangunan Nasional "Veteran" Yogyakarta, a doctoral student in PDIE \\ (Doctoral Program in Economics), Universitas Sebelas Maret Surakarta (Indonesia) \\ ${ }^{2}$ Faculty of Economic and Business, Universitas Sebelas Maret, Surakarta (Indonesia) \\ titik.kusmantini@upnyk.ac.id, tulusharyono@gmail.com,wisnu.untoro@gmail.com,aikhwansse@gmail.com
}

Received: May 2018

Accepted: July 2018

\begin{abstract}
:
Purpose: This study aims to identify whether the higher degree of fit between supply chain strategy and manufacturing strategy will result in a better performance. When the choice of supply chain technology (integrative SC technology and functional SC technology) to support the alignment of the strategy will then strengthen the relationship between degree of fit with performance.
\end{abstract}

Design/methodology/approach: Strategic alignment test between the functions uses 102 SMEs (Small and Medium Enterprises) in Yogyakarta Province, Indonesia with purposive sampling technique. The data are collected by distributing questionnaires to the companies that qualify the criteria of the sample, respondent target are procurement manager or production manager.

Findings: Samples are grouped into two ideal types of strategies used mean split technique. 53 SMEs adopt ASCS (Agile Supply Chain Strategy) and 49 SMEs adopt LSCS (Lean Supply Chain Strategy). Two of the strategy groups have a low value of misfit score; it means that the degree of fit between supply chain strategy and manufacturing strategy is high. The result of the hierarichal moderated regression test shows that a regression coefficient values is negative both in LSCS and ASCS group, but the hypothesis test is only proven on ASCS group while LSCS group is not significant. The test of the moderate effect of the choice of SC technology on the two strategy groups is proved to be significant.

Research limitations/implications: (1) The empirical finding of bivariate fit model test encourage a research space to explore the other contingent variable besides manufacturing strategy. For example, other function or corporate strategy. (2) The measurement of the company performance becomes the objective of the success of the alignment of supply chain strategy with the contingent variable which should be specified using the supply chain performance.

Originality/value: The use of Euclidean distance formula is expected to cover the technical limitations of contingency test by using interaction approach between the complex variables; the value of misfit score reflects the extent to which program alignment between the company functions.

Keywords: misfit score, euclidean distance, mean split, contingent variable, simple regression technique 


\section{To cite this article:}

Kusmantini, T., Haryono, T., Untoro, W., \& Setiawan, A.I. (2018). Strategic Consensus Between Functions and the Role of Supply Chain Technology as Moderator. Journal of Industrial Engineering and Management, 11(4), 735748. https://doi.org/10.3926/jiem.2652

\section{Introduction}

Globalization has an impact on the level of business competition that is increasingly competitive and has changed the phenomenon of business competition which is no longer based on the ability of individual companies, but based on the supply chain. The focus of research on supply chain strategy sees interdependency issues among companies as a critical issue that needs to be managed well in an effort to improve company performance. The empirical concept of strategic alignment or strategic fit in the past two decades has prompted a number of researchers because of empirical evidence that the direct impact of supply chain strategy on performance has not been conclusive.

Venkatraman and Camillus (1984) and Kathuria, Joshi and Porth (2007) stated that the concept of strategic alignment or fit is one important thing in the process of strategy formulation and implementation. Recently, the topic of strategic alignment or fit has become a major and popular topic in strategic management research (Tan \& Tan, 2005; Han, Wang, \& Naim, 2017). Considering the critical role of the strategy as the direction for the company in order to achieve the short-term business goals and encourage the company's ability to survive in an increasingly competitive era, some strategy management researchers are more interested in assessing the effect of strategic alignment on performance rather than assessing the strategy practice directly on performance.

Porter (1980) defines the concept of strategy alignment as a critical and fundamental element that should be pursued by all companies because it is not only able to create a competitive excellence, but also able to create the sustainable competitive excellence of the company. Porter also defines strategic alignment as an effort that needs to be pursued by the company in order to create alignment efforts between the activities in the internal scope of the company. Hitt (2011) explain the importance of internal alignment, especially on strategy charges that will be decided in the strategy formulation process. The term of alignment reflects the congruency or consistency of decision.

Kathuria et al. (2007) explains a hierarchy of strategic alignment in various stages of relation, for example, vertical fit, horizontal fit and intra-fit activity in function. The vertical fit is an alignment effort of a strategic goal in the corporate level or a higher level for the existing of strategic alignment it needs to be translated into a number of strategic actions and programs in the lower organization functional level. The vertical fit test reflects the existing of corporate strategy alignment with functional level or business unit level strategy of the company. While the horizontal fit is an alignment effort of strategic decision between the organizational functions. Hofmann (2010) emphasizes the need for strategic fit and alignment inter-functional. Some researchers focus on strategic alignment test horizontally, for example, the alignment study of operating strategy and information technology (IT) strategy relation carried out by Boon-itt and Wong (2011) and Bhattacharya (2017). The test research of the alignment of supply chain and of operating or manufacturing strategy is done by Banchuen, Sadler and Shee (2017), Chan, Ngai and Moon (2016), Cagliano, Caniato and Spina (2006) and Swink, Narasimhan and Kim (2005). In fact, an organization is always constrained by the development of the coherent strategic programs between the functions. The alignment is often constrained by the appearance of a conflict of interest between the functions (Swink et al., 2005). Strategic alignment relation is horizontally also able to eliminate the conflict of interest between the functions (Meyer, Tsui, \& Hinings, 1993), then the higher strategic alignment between functions will effect on the creation of a better company performance.

Kathuria et al. (2007) classify the level of strategic alignment into several categories; they are high, medium and low alignment level where every level requires the different managerial actions. According to Venkatraman (1989), two domains of fit in addition to the alignment of strategy content, it is necessary to have an effective managerial pattern in the execution process of the alignment strategy. In this study, the managerial focus is on technology 
management to create the flexibility of supply and manufacturing processes. Therefore, there are two problems of this research, namely: (1) whether the higher degree of fit between supply chain strategy and manufacturing strategy will create better performance. (2) Whether the selection of SC technology types aligned with strategy choices will strengthen the relationship of strategic fit between function with performance.

\section{Literary Research and Hypothesis Development}

\subsection{The Conception and Typology of Supply Chain Strategy}

The development of the concept of supply chain strategy is an expansion of the concept of supply chain management (SCM). The concept of SCM itself is first discussed by Forrester (1961) when the researchers have indicated the dynamics of the company's response on the demand changes in various situations or contexts of different companies. Forrester has indicated that there are different types of demand distortion as a consequence of the process dynamics complexity on-demand information transfer from downstream to upstream; the more upstream fluctuating information indicates increasingly high demand. Forrester emphasizes that the key to the success of managing the supply chain is a strategy to manage aspects of interdependencies among all participants linked along the supply chain to have responsibility together in order to maximize the performance with all inherent limitations in the existing supply chain system. Table 1 elaborates the development of the conception definition of supply chain strategy.

\begin{tabular}{|c|c|c|}
\hline Researcher(s) & The conception of SCS definition & Dimensions/Indicators \\
\hline $\begin{array}{l}\text { Christopher \& Towill, 2000; } \\
\text { Sreedevi \& Saranga, } 2017\end{array}$ & $\begin{array}{l}\text { A set of strategic programs and } \\
\text { actions along the supply chain which } \\
\text { are able to create reconciliation } \\
\text { between customer needs by the extent } \\
\text { to which resource capacity that can be } \\
\text { found along the supply chain. }\end{array}$ & $\begin{array}{l}\text { The dimensions of Agile supply chain strategy: } \\
\text { powerful imaging, high-quality product; } \\
\text { collaborative product configuration, pro-active } \\
\text { management structure and the balance of supply } \\
\text { process. }\end{array}$ \\
\hline $\begin{array}{l}\text { Simchi-Levi, Simchi-Levi \& } \\
\text { Kaminsky, 1999; Hilletofth, } \\
\text { 2009; Marsilac \& Roh, } 2014\end{array}$ & $\begin{array}{l}\text { A process of managing supply chain } \\
\text { activities which are focused on } \\
\text { improving customer satisfaction } \\
\text { through the activities of sustainable } \\
\text { value creation. }\end{array}$ & $\begin{array}{l}\text { Identification of trigger source of waste in the } \\
\text { supply chain: excess production capacity; delivery } \\
\text { delay; excess inventory; additional processing time; } \\
\text { waiting time, low shop floor work motivation and } \\
\text { defective products. }\end{array}$ \\
\hline $\begin{array}{l}\text { Huang, Uppal \& Shi, 2002; } \\
\text { Tolanen, Haapsalo, Harkonen } \\
\text { \& Verrollot, } 2017\end{array}$ & $\begin{array}{l}\text { An alignment effort and integration of } \\
\text { activities in the supply chain to create } \\
\text { superior performance. }\end{array}$ & $\begin{array}{l}\text { Strategy orientation; supplier selection; inventory } \\
\text { strategy; management of waiting time; production } \\
\text { capacity strategy and product development strategy. }\end{array}$ \\
\hline $\begin{array}{l}\text { Cagliano, Caniato \& Spina, } \\
\text { 2004; Kim, 2006; } \\
\text { Narasimhan \& Jayaram, 1998; } \\
\text { Yinan, Baofeng, Zheqiang \& } \\
\text { Hoi, } 2017\end{array}$ & $\begin{array}{l}\text { A development effort of management } \\
\text { activities within an integrated supply } \\
\text { chain. }\end{array}$ & $\begin{array}{l}\text { Two dimensions: (1) integration of logistic activity } \\
\text { in the upstream and downstream; (2) the dimension } \\
\text { of internal integration of functions such as } \\
\text { operating, marketing, system and information } \\
\text { technology and product development function. }\end{array}$ \\
\hline $\begin{array}{l}\text { McKone-Sweet \& Lee, 2009; } \\
\text { Nakano, 2015; Magutu, } \\
\text { Aduda \& Nyoga, } 2015\end{array}$ & $\begin{array}{l}\text { An alignment development of } \\
\text { management activity process in the } \\
\text { supply chain is integrated with the } \\
\text { organizational context in order to } \\
\text { create a better company performance. }\end{array}$ & $\begin{array}{l}\text { Six dimensions: organizational planning, internal } \\
\text { functions integration, supplier relationship } \\
\text { management, customer relationship management, } \\
\text { IT for exploitation and exploration. } \\
\text { Different level of achievement IT: integratative SC } \\
\text { technology and functional SC technology. }\end{array}$ \\
\hline
\end{tabular}

Table 1. Various opinions about the conception of SCS

In this study, two ideal types of supply chain strategy assessed are Agile Supply Chain Strategy (ASCS) and Lean Supply Chain Strategy (LSCS). Responsiveness is a priority orientation of the type of agile supply chain strategy. The following are several definitions of supply chain strategy conception defined by supply chain strategy researchers. The concept Agility is stated by Christopher and Towill (2000) as a concept that promotes the responsiveness and the ability to adjust to the demand for deals in the market which is volatile and unpredictable. Boon-itt and Wong (2011) emphasize that the importance be agile no longer refers to forecasting-driven but rather 
refers to demand-driven. While (Christopher \& Holweg, 2011) has defined agility as the ability to respond the market change to the efficient and profitable cost.

While in implementing Lean Supply Chain Strategy (LSCS), the companies generally adopt lean manufacturing idea which is first described by (Womack, Jones, \& Roos, 1990) and then the concept is more broadly developed as lean thinking (Christopher, Peck, \& Towill, 2006). According to (Christopher et al., 2006), the focus of lean thinking is on the efforts of decreasing or eliminating waste or known as "muda". (Christopher \& Towill, 2000) also emphasizes that the concept of leanness which the meaning is so contradictory to the concept of agility because leanness is interpreted as doing more with less while agility has the orientation of ability to respond quickly, then the consequence that must be accepted is an increased cost that may arise.

\subsection{The Conception and Typology of Operating Strategy}

The important role of the operating function is able to produce products and services that satisfy the customers. Hilletofth (2009) mention that operating function becomes a profit-producing machine of the company. The company is to be able to align strategic programs and actions in each functions. Kathuria et al. (2007) and Baier, Hartmann, and Moser (2008) opinions describe the importance of alignment between organizational functions as an effort to create an agreement among the managers in the formulation and implementation of strategy at the functional level.

The test research of the alignment concept of manufacturing strategy either research on the taxonomy or typology of manufacturing strategy can be concluded for a while that there are two types of ideal manufacturing strategy, they are: (1) focus on the excellence in operational field due to the ability to create unique/distinctive matter and (2) focus on the excellence in the field of operation due to the ability to create using the lowest production cost. Table 2. summarizes the concept of manufacturing strategy and the development of these variables measurement. According to Shavarini and Salimian (2013), the literary construct of manufacturing strategy was first initiated by Skinner (1969) and if the development of empirical research is observed, it seems the concept of manufacturing strategy is consistent as defined by Skinner. Generally, the difference of one research with the others is focused on dimensional competitive priorities or manufacturing capabilities measurement.

\begin{tabular}{|l|l|l|}
\hline \multicolumn{1}{|c|}{ Researcher(s) } & \multicolumn{1}{c|}{ Concept definition } & \multicolumn{1}{c|}{ Dimensions/Indicators } \\
\hline $\begin{array}{l}\text { Skinner, 1969; Huang et al., } \\
\text { 2002; Zhao, Sum, Qi, Zhang } \\
\text { \& Lee, 2006; Kim, 2006; } \\
\text { Banchuen et al., 2017; } \\
\text { Sreedevi \& Saranga, 2017 }\end{array}$ & $\begin{array}{l}\text { Is a functional strategy level which is } \\
\text { encouraged to generate a competitive } \\
\text { excellence in the field of operation that } \\
\text { can be used to encourage the company } \\
\text { to maintain a competitive position }\end{array}$ & $\begin{array}{l}\text { 4 dimensions of manufacturing strategy, they are } \\
\text { competing priorities in terms of (1) cost leadership } \\
\text { (2) the superiority of quality; (3) the speed of } \\
\text { delivery and delivery reliability; (4). Flexibility: } \\
\text { capacity and introduction a new product. }\end{array}$ \\
\hline $\begin{array}{l}\text { Zhao et al., 2006; Nakano, } \\
\text { 2015; Yinan et al., 2017 }\end{array}$ & $\begin{array}{l}\text { Is a functional strategy level which is } \\
\text { encouraged to generate a competitive } \\
\text { excellence in the field of operation that } \\
\text { can be used to encourage the company } \\
\text { to maintain a competitive position }\end{array}$ & $\begin{array}{l}\text { Develop manufacturing strategy dimension into 8 } \\
\text { dimensions: (1) the cheap production cost; (2) the } \\
\text { flexibility of the process; (3) the flexibility of the } \\
\text { product; (4) the quality; (5) the reliability of the } \\
\text { product; (6) the speed of delivery; (7) the delivery } \\
\text { dependency and (8) innovation. }\end{array}$ \\
\hline $\begin{array}{l}\text { Zhao et al., 2006; } \\
\text { Sambultawee \& Boon-itt, } \\
2017\end{array}$ & $\begin{array}{l}\text { Is a functional strategy level which is } \\
\text { encouraged to generate a competitive } \\
\text { excellence in the field of operation that } \\
\text { can be used to encourage the company } \\
\text { to maintain a competitive position }\end{array}$ & $\begin{array}{l}\text { Develop manufacturing strategy dimension into 10 } \\
\text { dimensions by adding a dimension of product and } \\
\text { design quality. }\end{array}$ \\
\hline
\end{tabular}

Table 2. Various opinions about the conception of manufacturing strategy

\subsection{The Framework for the Development of an Empirical Model of Strategic Alignment}

Fit and Alignment term have the same meaning, but in the strategic management literature the term of fit is more widely used while in the organizational theory literature or economic theory of industrial organization more uses 
the term of alignment. The fit is seen as the fundamental in the strategic management literature for several reasons as follows:

(1) The concept of fit in its application in the field is seen as a business policy, initiated the concept of fit within the paradigm of the strategy was first written by Schandel and Hofer (1979) which is also referred to as matching or aligning (alignment) organizational resources with the opportunities and the threats that exist in the environment;

(2) The fit is seen as a research method and the definitions of the alignment concept are very diverse according to the disciplines, therefore the development of fit conception test is wider. The alignment research refers to several theories, they are IO economic (Porter, 1981); administrative behavior theory (Jemison, 1981); marketing theory (Biggadike, 1981) and still broadly.

(3) The concept of fit by Hofer (1975) is widely used in the research of strategy based on a contingency approach. Many studies have been conducted to test the concept of fit implicitly and explicitly. Contingency research has explored a number of contingent factors of a company that may effect on the strategy formulation (Venkatraman \& Camillus, 1984) and it has resulted in the construction of new theory namely contingency theory. Initially, most contingency research aims to test the concept of fit in terms of the alignment of a strategy relation with one single contingent variable (and fit of strategy relation with a contingent variable is called bivariate fit model test.

(4) The concept of fit is seen as a normative concept that has been believed by strategists as the critical in terms of synchronizing the complexity of company elements in order to function effectively in supporting the implementing process of a company's chosen strategy (Delery \& Doty, 1996).

(5) The concept of strategic alignment refers to the concept of fit that has been developed by Venkatraman \& Camillus (1984) and Van de Ven \& Drazin (1985). When using configuration perspective, the concept of fit reflects the existence of alignment between multiple variables that must be considered simultaneously (Baier et al., 2008). In this study, the tested concept of fit is the alignment of strategy relation between the functions and the configuration of strategy is illustrated in Figure 1.

Figure 1. illustrates the empirical model of the alignment influence of supply chain strategy relation with manufacturing strategy and its impact on company performance. The pattern of strategic alignment will be classified into two ideal groups which in the mainstream have the contrary oriented strategy, they are the ideal type of supply chain strategy classified into two types namely the type of agile and lean. While manufacturing strategy is also classified into two types, they are the type of differentiators versus efficient-innovators. Theoretically, the type of agile is appropriate with the type of differentiators, while the type of lean is appropriate for the type of efficient-innovators. Referring to the opinion of Magutu et al. (2015), he states that the execution of supply chain strategy choices will effectively create performance moderated by the level of integrated supply chain development capability, whether it is more focused on internal integration or external integration. Magutu et al has distinguished the type of technology that can be chosen according to the orientation of the supply chain strategy. When it uses quick response-oriented approach, it is more consistent with the integrative SC technology and when it orients towards efficiency, it is more suited to functional SC technology. This is in line with the opinion of Yinan et al. (2017) who holds technological alignment as a leverage factor of alignment of manufacturing strategy and supply chain strategy with performance. Supply chain strategy groups which are oriented on speed in responding a change focuses on supply flexibility, while efficiency-oriented ones focus more on manufacturing flexibility (Sreedevi \& Saranga, 2017). 


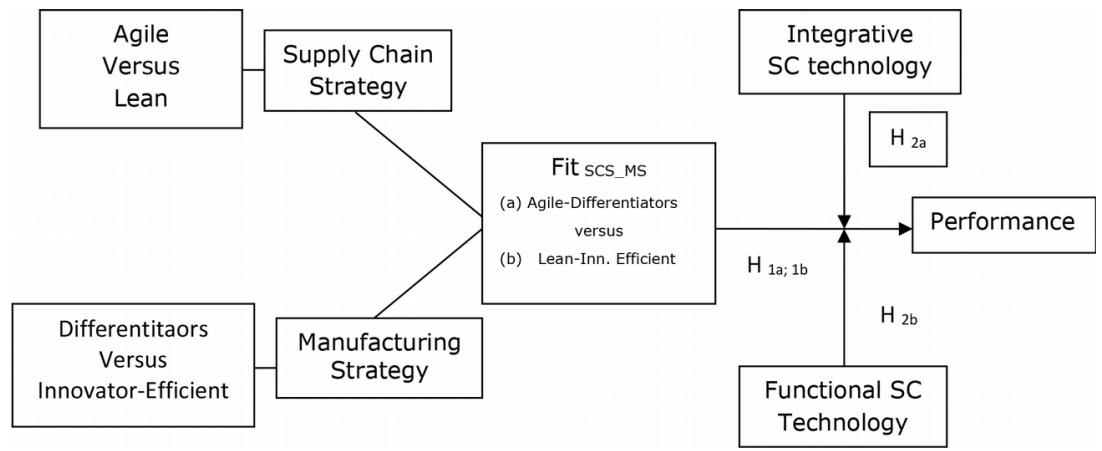

Figure 1. Empirical Model

\subsection{The Alignment of Supply Chain Strategy with Manufacturing Strategy and the Development of a Hypothesis}

Related to the implementation process of strategy, some experts of strategic alignment stresses that strategic alignment is viewed from various perspectives, such as strategic alignment by the organizational context (Stonebraker \& Liao, 2004; Huang et al., 2002); strategic alignment vertically and horizontally (Kathuria et al., 2007). Vertical fit shows the alignment of functional strategy relation with corporate or business strategy because miss link/misalignment or inability to translate the goals in the company level into the functional area will result in a bad performance (Skinner, 1969; Kathuria et al., 2007).

While the horizontal or lateral fit is a strategic decision consistency between the functions, supply chain strategy practice is very closely with strategy in manufacturing field (Cagliano et al., 2006). This is confirmed by Frohlich and Westbrook (2001) which also emphasizes that the alignment and the connectedness of internal processes in the scope of manufacturing function with external processes both upstream and downstream will create the overall business process efficiency. Thus, the selection of competing priorities in the field of manufacturing must be translated to the strategic activities and decisions in the scope of suppliers or consumers.

The result of a survey conducted by Tamas (2000) in a number of a manufacturer in the US concludes that of the 80 companies only $13 \%$ have been able to fit the selection of priorities in manufacturing function with supply chain activities in the scope of suppliers and customers. Banchuen et al. (2017) introduce four selections of competing priorities in the field of operating or manufacturing. These are a trade-off or interchangeable in nature. It reflects that the selection of supply chain strategy will determine the selection of competitive priorities in the different manufacturing field. Four competitive priorities as manufacturing strategy dimensions are product quality, pioneering in the production cost, fast delivery and flexibility level. Competitive priorities in the production field such as pioneering in the production cost will support the achievement of a better performance if the orientation of supply chain strategy focuses on the efficiency of the supply process (McKone-Sweet \& Lee, 2009; Yinan et al., 2017) Otherwise, the responsive orientation of supply chain strategy will be achieved if the company is able to achieve the excellence of quality and flexibility performance (McKone-Sweet \& Lee, 2009; Marsilac \& Roh, 2014; Banchuen et al., 2017). Referring to the conceptualization of the relation alignment of supply chain and manufacturing strategy and the impacts on the performance, the research hypothesis that is proposed is as follows:

H1a: The higher degree of fit between supply chain strategy and manufacturing strategy (ASCS_differentiators), it can improve high company performance.

H1b: The higher degree of fit between supply chain strategy and manufacturing strategy (LSCS_innovators-efficient), it can improve bigh company performance.

\subsection{The Alignment Type of SC Technology and the Development of a Hypothesis}

Supply chain readiness reflects the company's ability to manage cooperation networks along the supply chain in order to create value (Sambultawee \& Boon-itt, 2017; Tolanen et al., 2017). Some researchers emphasize the importance of supply chain integration (Marsilac \& Roh, 2014; Budiarto, Prabowo \& Herawan, 2017), but according to Magutu et al (2015), the alignment of SC technology development with the orientation of supply 
chain strategy will be able to create better performance. Magutu et al has provided empirical evidence that the functional type SC technology is able to moderate the LSCS relationship on performance and integrative types of SC technology also proved to be able to strengthen ASCS relationship on performance. Yinan et al. (2017) and Sreedevi \& Saranga (2017) suggest that when process flexibility is a priority program in manufacturing, it will succeed when companies are able to increase supply flexibility. Yinan et al. further explains that integrating company activity with suppliers will improve first entry-to-market capabilities. An important step in the product development process is the development of supply chain integration for new product production processes (Tolonen, et al., 2017) and external integration will shorten the development cycle of new products (Marsilac \& Roh, 2014).

Generic type linkages of Supply chain strategy are also examined by Hallgren and Olhager (2009) and the results provide empirical evidence that LSCS types will produce better performance when companies implement a make-to-stock production system, while ASCS types have contradictory priorities more suited to make-to-order production system. Nakano (2015) reinforces the different assignment structures in the ASCS group with the LSCS, internal integration aimed at sharing data and information across functions will minimize conflict between functions and encourage the ability to eliminate "waste". Referring to the results of previous research, the proposed statement of second hypothesis in this study is

$$
\begin{aligned}
& H_{2 a} \text { : Integrative Supply Chain Technology is able to moderate the relationship of strategic fit between function } \\
& \text { (ASSCS_differentiators) on performance. } \\
& H_{2 b} \text { : Functional Supply Chain Technology is able to moderate the relationship of strategic fit between function } \\
& \text { (LSCS_innovator-efficient) on performance. }
\end{aligned}
$$

\section{Research Method}

\subsection{The Research Sample and Sampling Technique}

The research samples are mostly manufacturing SMEs in Yogyakarta region. The specific reason for selecting SMEs is the government policy to encourage the opportunity of investment foundation to local companies is continually intensified, considering the prospect and the contribution of SMEs to GDP (Gross Domestic Product) of Special Region of Yogyakarta Province, Indonesia, lately is increased and the growth contribution of export value is also significant.

Sampling design utilized in this study is not a random sampling because it uses several criteria as a condition or consideration for choosing a sample or called by purposive sampling technique (Hair, Anderson, Tatham, \& Black, 2005). Considering the problems of the study is to assess the extent to which the strategic planning process, especially in the development of supply chain capabilities, the manufacturing companies that will be selected as the samples must possess these three criteria: (1) export-oriented SMEs; (2) SMEs possessing a website to manage the marketing and supply process; (3) SMEs possessing more than 50 employees and have the divisions or functions such as IT, marketing, finance and quality control division. Some of these assessed criteria should be considered in order to obtain a representative company to illustrate the ability to manage a better supply chain strategy.

\subsection{Measurement Scale and Operational Definition of Variables}

The variable measurements in this study used a bipolar semantic differential with a weight rating of 1 to 7 , where the answers close to 1 indicate the choice of the left extreme strategy (LSCS, innovators-efficient and functional sc technology). While the answers close to 7 reflect the perception of respondents' choice on the type of ASCS strategy, differentiators and integrative sc technology. Table 3 describes the complete definition of operationalization of variables and dimensions of each variable.

\subsection{Validity and Reliability Test}

The validity test uses Confirmatory Factor Analysis technique, cut off value to declare the valid and reliable instrument refers to eigenvalue and Cronbach alpha which must be greater than 0.5 (Hair et al., 2005). The validity test of six variable indicators of supply chain strategy results in eigenvalue of more than 0.5 which is between 0.501 
- 0.874, which means that all SCS indicators are valid. Likewise, for the variables of manufacturing strategy and company performance, it also results in eigenvalue of more than 0.5 which is consecutive to manufacturing strategy between 0.602 to 0.908 , while the company performance between 0.734 to 0.856 . However, there is one invalid indicator in $6 \mathrm{SC}$ technology indicators because the eigenvalue is 0.463 and then it is not used for further analysis. While the reliability test result shows that all researched variables have a Cronbach alpha coefficient above 0.50, it means that it can be concluded that all variables used in this study are reliable. The value of variable SCS Cronbach alpha is 0.770 ; manufacturing strategy is 0.792 ; SC technology is 0,667 and company performance is 0.804 .

\subsection{Data analysis technique}

The degree of fit effect test of supply chain strategy relation with manufacturing strategy uses a configuration perspective technique that has been developed by Baier et al. (2008) by using Euclidean distance method conducted by previous researchers. They are Van de Ven and Drazin (1985), Venkatraman and Camillus (1984) and Priyono, 2004).

\begin{tabular}{|c|c|c|c|}
\hline Variable & Operational Definition & Dimension & Researchers \\
\hline $\begin{array}{l}\text { Supply Chain } \\
\text { Strategy } \\
\text { (Agile/ASCS } \\
\text { versus Lean/LSCS) }\end{array}$ & $\begin{array}{l}\text { Supply chain strategy is } \\
\text { defined as a set of strategic } \\
\text { programs and actions along } \\
\text { the supply chain which is able } \\
\text { to create reconciliation } \\
\text { between customer's needs to } \\
\text { supply chain resources } \\
\text { capability. }\end{array}$ & $\begin{array}{l}\text { (1). Planning coordination between the } \\
\text { functions } \\
\text { (2). Coordination capability of the } \\
\text { company with suppliers } \\
\text { (3). Cooperation with suppliers } \\
\text { (4). Cooperation with customers } \\
\text { Breakdown to } 19 \text { indicators }\end{array}$ & $\begin{array}{l}\text { Simchi-Levi et al., 1999; } \\
\text { McKone-Sweet \& Lee, } \\
\text { 2009; Hilletofth, 2009; } \\
\text { Nakano, 2015; Yinan et al., } \\
2017\end{array}$ \\
\hline $\begin{array}{l}\text { Manufacturing } \\
\text { Strategy } \\
\text { (Differentiators } \\
\text { versus Innovators- } \\
\text { efficient) }\end{array}$ & $\begin{array}{l}\text { a strategy in the functional } \\
\text { level which is encouraged to } \\
\text { result in a competitive } \\
\text { excellence in the field of } \\
\text { operation that can be used by } \\
\text { the company in maintaining } \\
\text { the company's competitive } \\
\text { position in the industry }\end{array}$ & $\begin{array}{l}\text { (1). High Quality } \\
\text { (2). Lowest cost } \\
\text { (3). Fast Delivery } \\
\text { (4). Delivery reliability } \\
\text { (5). Flexibility product } \\
\text { (6). Flexibility process } \\
\text { (7). Inovativeness } \\
\text { Breakdown to } 14 \text { indicators }\end{array}$ & $\begin{array}{l}\text { Sum, Kow \& Chen, 2004; } \\
\text { Zhao et al., 2006; Huang et } \\
\text { al., 2002; Yinan et al., 2017; } \\
\text { Sambultawee \& Boon-itt, } \\
2017\end{array}$ \\
\hline $\begin{array}{l}\text { SC Technology } \\
\text { (Integrative SC } \\
\text { technology versus } \\
\text { Functional SC } \\
\text { technology) }\end{array}$ & $\begin{array}{l}\text { As a tool to improve supply } \\
\text { flexibility and manufacturing } \\
\text { flexibility }\end{array}$ & $\begin{array}{l}\text { (1). Utilization data sharing } \\
\text { (2). Collecting customer feedback } \\
\text { (3). Beneficial of IT } \\
\text { (4). Joint decision making } \\
\text { (5). Focus of orientation IT strategy } \\
\text { (6). Time frame to adjustment data }\end{array}$ & $\begin{array}{l}\text { Magutu et al., 2015; Yinan } \\
\text { et al., 2017; Tolonen et al., } \\
\text { 2017; Budiarto et al., } 2017\end{array}$ \\
\hline Performance & $\begin{array}{l}\text { An achievement of } \\
\text { subjectively perceived non- } \\
\text { financial performance by the } \\
\text { business owner. }\end{array}$ & $\begin{array}{l}\text { (1) the efficiency of the process } \\
\text { (2) the reduction of production cost } \\
\text { (3) the speed in the delivery of products } \\
\text { (4) a rapidly respond to market changes } \\
\text { (5) the flexibility of the process } \\
\text { (6) the flexibility of production volume }\end{array}$ & $\begin{array}{l}\text { Zhao et al., 2006; } \\
\text { Sambultawee \& Boon-itt, } \\
2017\end{array}$ \\
\hline
\end{tabular}

Table 3. The definition of an operational variable

Hypothesis test uses simple linear regression test. The regression equation formulation is:

$$
Y=\beta_{0}+\beta_{1} \text { Dist X1.X2 }_{X}+\varepsilon
$$

$Y=$ the performance of SMEs as the dependent variable

$\beta_{0}=$ constants

$\beta_{1}=$ regression coefficient 
Dist $_{X 1 . X 2}$ is Euclidean distance supply chain strategy with a manufacturing strategy

Dist is the Euclidean distance or misfit score between the variables of supply chain and manufacturing strategy which the process of calculating the value of the Euclidean distance is by summing up the amount of deviation or the difference of the ideal score for each group of ideal strategy with the following formula:

$$
\text { Dist }=\sum \sqrt{ }\left(X_{\text {ideal }}-X_{\text {actual }}\right)^{2}
$$

$X_{\text {ideal }}$ is the amount of ideal score of contingency variable (manufacturing strategy)

$X_{\text {actual }}$ is the amount of actual score of contingency variable (manufacturing strategy)

This simple linear regression model does not use time series data, and in behavioral studies are not aimed to predict a phenomenon but aim to explain a phenomenon. Therefore, this study is not carried out a classical assumption test. In a behavioral study of individual or organization that should be observed is multi-coloniarity which is the perfect relation between the independent variables in the regression equation model. However, because the regression equation used is simple regression equation, in which the independent variable is only one and comes from Euclidean distance score or supply chain strategy deviation with the contingent variable, it is concluded that multi-coloniarity would not occur in this model. The initial sample step will be classified into two groups of strategy by using mean value to split the sample (called mean split). If the perceived mean value of supply chain strategy is above the sample mean value, it will be classified into the ideal type of agile strategy. If the result is below the mean, it will be classified as lean type.

\section{Findings}

\subsection{Statistical Description of Variable Research}

Table 4 presents a statistical description of variable research and the initial test step will split the sample into two groups, they are a sample of SMEs that implement type 1 of supply chain strategy (Agile Supply Chain Strategy) and type 2 (Lean Supply Chain Strategy). The sample splitting technique is based on the mean split value of perceived procurement manager, production and IT on the research variables. Should respondents answer score is above samples mean sore, then it will be coded 1 as ASCS type. A score below variable mean score will be coded 2 as LSCS type.

\begin{tabular}{|c|c|c|c|c|c|c|c|}
\hline \multirow[b]{2}{*}{ Variable } & \multicolumn{2}{|c|}{ Ideal score total } & \multicolumn{2}{|c|}{ Actual score total } & \multirow[b]{2}{*}{ Range } & \multirow[b]{2}{*}{ Mean } & \multirow{2}{*}{$\begin{array}{l}\text { The standard } \\
\text { of deviation }\end{array}$} \\
\hline & Range & Mean & Min & Max & & & \\
\hline Supply Chain Strategy & $19-133$ & 76 & 71 & 124 & 26.5 & 99.16 & 11.38 \\
\hline Manufacturing Strategy & $14-98$ & 56 & 60 & 93 & 16.3 & 77.75 & 6.71 \\
\hline SC Technology & $5-35$ & 21 & 15 & 28 & 5 & 20,75 & 3,11 \\
\hline Performance & $6-42$ & 24 & 18 & 30 & 6 & 24.71 & 3.08 \\
\hline
\end{tabular}

Table 4. The summary of ideal score total versus real total score variable

The assumption of the ideal score for Agile supply chain strategy type is 7 , while the type of Lean is 1 , so if the number of question items of supply chain strategy is 19 statement items, then the range of the ideal score is 19 to 133. While the question items of manufacturing strategy are 14 items, then the range of the ideal score is 14 to 56 ; SC technology have 5 indicators (one indicator removed) so the ideal score is 5 to 35 and the performance is 6 to 42 because have 6 indicators. For classifying the sample, the researcher used the actual mean value 99.16. If the actual mean value is more than the sample mean, it is classified as Agile supply chain strategy (ASCS) group (or code 1). While the Lean group of supply chain strategy (LSCS) is coded 2 if the actual mean value is less than sample mean. If the actual mean value for the three variables is more than the ideal mean value, it means there are more Agile strategy groups. There are 53 companies for Agile strategy groups, while there are 49 companies for Lean groups. 


\subsection{The Description of Misfit Score and the Influence of Strategic Alignment to the Performance}

The next step is to calculate the distance value or Euclidean distance which is subjectively perceived difference score on the assessment of existing ideal strategy practice. Euclidean distance value will function as a predictor variable that allegedly capable to affect performance. If misfit score is high, it is assumed that misalignment is high hence decreasing performance. And then if misfit score is low, it indicates have alignment and increased performance. Thus, the test result using simple regression resulted in a negative coefficient value of beta standardized, it can be concluded that the hypothesis is valid. Table 5. present a summary of simple regression for supply chain strategy groups.

Regression coefficients which are shown in Table 5 are the statistical values to test the hypothesis whether a higher degree of relation fit in each group of supply chain strategy effects on the creation of a higher performance. Beta coefficient value for the two types of supply chain strategy results in a negative regression coefficient value which means having the best relationship that the higher value of misfit score resulting in lower performance. It can be interpreted that if the value of misfit score is lower, it reflects a high degree of fit (Baier et al., 2008). The test of ASCS group by using one-tailed test results a significance value $<0.01$ which means that the research hypothesis of ASCS group is supported. The empirical meaning is evidence that ASCS group has a higher degree of relation fit and significantly influences on the group performance creation better than the LSCS group. Otherwise, the hypothesis of LSCS group is not supported because the significance value is $>0.05$ despite the regression coefficient value is negative or reflects the inverse relation between misfit score strategy with the performance but the effect is not significant statistically. The role of SC technology as a moderating variable, the result of the test with tiered regression technique resulted in increased adjusted $\mathrm{R}$ square value and consistently negative in the ASCS group. This means that functional type technology of SC technology is able to strengthen the relationship of strategic fit with performance. Likewise in the LSCS group that was initially not significant, integrative practices of SC technology can improve the influence of strategic fit on performance.

\begin{tabular}{|c|c|c|c|c|c|}
\hline Simple Regression Equation Model & $n$ & $R^{2}$ & $\begin{array}{l}\text { Constanta } \\
\left(a_{1} ; a_{2} ; a_{3} ; a_{4}\right)\end{array}$ & $\begin{array}{l}\text { Beta coefficient } \\
\qquad\left(\boldsymbol{b}_{1} ; \boldsymbol{b}_{2} ; \boldsymbol{b}_{3} ; \boldsymbol{b}_{4}\right)\end{array}$ & $t_{\text {count }}$ \\
\hline$Y=a_{1}+b_{1} \operatorname{Dist}_{(\text {Agile } X 1 X 2)}+e$ & 53 & 0.105 & 34.671 & $-0.350^{*}$ & -2.668 \\
\hline $\mathrm{Y}=a_{2}+b_{2} \operatorname{Dist}_{(\mathrm{LeanX} 1 \mathrm{X} 2)}+e$ & 49 & -0.160 & 30.421 & -0.069 & -0.475 \\
\hline $\mathrm{Y}=a_{3}+b_{3} \operatorname{Dist}_{(\text {Agile) }} * \mathrm{Z}+e$ & 53 & -0.241 & 32.361 & $-0.173^{*}$ & -0.562 \\
\hline $\mathrm{Y}=a_{4}+b_{4} \operatorname{Dist}_{(\text {Lean })} Z+e$ & 49 & -0.126 & 30.322 & $-0.134^{*}$ & -0.411 \\
\hline
\end{tabular}

$*$ significance on $p<0.01$ (one-tailed test)

** significance on $p<0.05$ (one-tailed test)

Table 5. The Summary of Regression Influence

\subsection{Discussion}

The result of this research concludes that the hypothesis 1 either the type of ASCS ideal strategy or LSCS type 2 is not fully supported because the degree of relation fit of supply chain strategy in Lean group supply chain strategy with manufacturing strategy does not significantly affect on the performance. If it is observed, the regression coefficient value results in a negative value which means that if the value of misfit score is higher, the performance becomes low or vice versa, but its influence indicates that the LSCS does not have a significant effect for resulting probability value $>0.05$. Contingent test by using a bivariate model or test a single contingent variable, some researchers of configuration also resulted in confusing findings (Baier et al., 2008; Riyanto, 1999; Priyono, 2004; Kusmantini, 2006, 2007). The result of this research is consistent with the research of (Banchuen et al., 2017) and (Cagliano et al., 2004) which also assessed on the degree of fit of SCS relation with manufacturing strategy. The early result of the research concludes that not all types of strategy have strategic alignment and the higher degree of the alignment relation of supply chain strategy with manufacturing strategy is able to create a higher performance. The result of taxonomy study of supply chain strategy which is carried out by (McKone-Sweet \& Lee, 2009) also identifies that the resulted taxa of strategy from cluster analysis are proven to have a different 
orientation of supply chain capabilities and a selection of competitive priorities, but strategic alignment is only in agile type while there is no alignment on two other types such as lean and hybrid.

This study also examines the role of choice of SC technology type developed by Magutu et al. (2015), and the test results provide empirical evidence that when the company is oriented to quick response and product uniqueness, efforts to develop cooperation with external parties, such as suppliers, can strengthen the influence of strategic fit between function with performance. The results of this study are in line with Tolanen et al. (2017) that companies focusing on supply flexibility will have better supply chain readiness in new product development processes, this is achieved because the companies are: (1) maintaining flexible supply; (2) developing collaboratives and (3) have joint decision making with suppliers (Yinan, et al., 2017; Sreedevi \& Saranga, 2017). On the other hand, in the cost-centered LSCS group (Magutu et al., 2015), functional practice of SC technology will assist the companies in improving manufacturing flexibility (Tolanen et al., 2017). The companies' advantage over the ability to develop manufacturing flexibility is the opportunity to cut costs and time (Marsilac \& Roh, 2014). According to Yinan et al. (2017), manufacturing flexibility is achieved through (1) maintaining excess capacity; (2) maintaning excess labor and (3) product postponement. The functional practices of SC technology will encourage LSCS group to increase manufacturing flexibility as there is an effort to share master production schedules across functions.

\section{Managerial Implication}

While the horizontal or lateral fit is a strategic decision consistency between the functions, supply chain strategy practice is very closely with strategy in manufacturing field. This is confirmed by (Frohlich \& Westbrook, 2001) which also emphasizes that the alignment and the connectedness of internal processes in the scope of manufacturing function with external processes both upstream and downstream will create the overall business process efficiency. Thus, the selection of competing priorities in the field of manufacturing must be translated to the strategic activities and decisions in the scope of suppliers or consumers. The results of this study are expected to provide insight for practitioners about the importance of SC technology development to be able to support the achievement of the alignment orientation strategy that has been formulated. When companies are oriented towards quick response, the development of collaboration in supply chain is a priority. As with the LSCS group that wants efficiency across the board, internal integration priorities are preferred to respond to economic changes.

Thus, the future studies need to consider strategic alignment vertically that is to consider the alignment of functional strategy with the competitive strategy of the company and also to consider the contingent aspect of external environment such as social capital as the context of the supply chain network of the company that can also affect performance. The alignment test of supply chain strategy relation with several contingent variables will provide a more conclusive result. This is consistent with the opinion of (Hofmann, 2010) that the formulation process of the content of the strategy is a complex strategic decision because it needs to consider the organizational context factor and the existence of interrelated-bundles issue between the resources.

\section{Declaration of Conflicting Interests}

The authors declared no potential conflicts of interest with respect to the research, authorship, and/or publication of this article.

\section{Funding}

The authors received no financial support for the research, authorship, and/or publication of this article.

\section{References}

Baier, C., Hartmann, E., \& Moser, R. (2008). Strategic Alignment and Procurement Efficacy: an Exploratory Analysis of Their Impact on Financial Performance. Journal of Supply Chain Management, 44(4), 36-52. https://doi.org/10.1111/j.1745-493X.2008.00071.x

Banchuen, P., Sadler, I., \& Shee, H. (2017). Supply chain collaboration aligns order-winning strategy with business outcomes. IIMB Management Review, 29(2), 109-121. https://doi.org/10.1016/j.iimb.2017.05.001 
Bhattacharya, P. (2017). Modeling Strategic Alignment of Business and IT through Modelling Architecture: Augmenting Archimate with BMM. In Procedia Computer Science, 121, 80-88. Elsevier. https://doi.org/10.1016/j.procs.2017.11.012

Biggadike, E.R. (1981). The contribution of marketing to strategic management. Academy of Management Review, 6(3), 621-632. https://doi.org/10.5465/amr.1981.4285710

Boon-itt, S., \& Wong, C.Y. (2011). The moderating effects of technological and demand uncertainties on the relationship between supply chain integration and customer delivery performance. International Journal of Physical Distribution \& Logistics Management, 41(3), 253-276. https://doi.org/10.1108/09600031111123787

Budiarto, D.S., Prabowo, M.A., \& Herawan, T., (2017). An Integrated information system to support supply chain management \& performance in SMEs. Journal of Industrial Engineering and Management, 10(1), 373-387.

https://doi.org/10.3926/jiem.2180

Cagliano, R., Caniato, F., \& Spina, G. (2004). Lean, Agile and traditional supply: how do they impact manufacturing performance? Journal of Procurement \& Supply Management, 10, 151-164.

Cagliano, R., Caniato, F., \& Spina, G. (2006). The linkage between supply chain integration and manufacturing improvement programmes. International Journal of Operations \& Production Management, 26(3), 282-299.

https://doi.org/10.1108/01443570610646201

Chan, A.T.L., Ngai, E.W.T., \& Moon, K.K.L. (2016). The Effects of Strategic and Manufacturing Flexibilities and Supply Chain Agility on Firm Performance in the Fashion Industry. European Journal of Operational Research, 6(3), 181-200.

Christopher, M., \& Holweg, M. (2011). Supply Chain 2.0: managing supply chains in the era of turbulence. International Journal of Physical Distribution \& Logistics Management, 41(1), 63-82.

https://doi.org/10.1108/09600031111101439

Christopher, M., Peck, H., \& Towill, D. (2006). A taxonomy for selecting global supply chain strategies. The International Journal of Logistics Management, 17(2), 277-287. https://doi.org/10.1108/09574090610689998

Christopher, M., \& Towill, D.R. (2000). Supply chain migration from lean and functional to agile and customised. An International Journal, 5(4), 206-213.

Delery, J.E., \& Doty, D.H. (1996). Mode of Theorizing in Strategic Human Resource management: Test of universalistic, Contingency and Configurational Performance Predictions. Academy of Management Journal, 39(4), 802-835. https://doi.org/10.5465/256713

Forrester, J.W. (1961). Industrial dynamics. England: MIT Press Cambridge MA.

Frohlich, M.T., \& Westbrook, R. (2001). Arcs of integration: an international study of supply chain strategies. Journal of Operations Management, 19, 185-200. https://doi.org/10.1016/S0272-6963(00)00055-3

Hair, J.F., Anderson, R.R., Tatham, R.L., \& Black, W.C. (2005). Multivariate Data Analysis. New Jersey: Prentice Hall International Inc.

Hallgren, M., \& Olhager, J., (2009). Lean and Agile Manufacturing: external and internal drivers and performance outcome. International Journal of Operation and Production Management, 29(10), 976-999.

https://doi.org/10.1108/01443570910993456

Han, J.H., Wang, Y., \& Naim, M. (2017). Reconceptualization of information technology fl exibility for supply chain management: An empirical study. Intern. Journal of Production Economics, 187(3), 196-215.

https://doi.org/10.1016/j.ijpe.2017.02.018

Hilletofth, P. (2009). How to develop a differentiated supply chain strategy. Industrial Management \& Data Systems, 109(1), 16-33. https://doi.org/10.1108/02635570910926573

Hitt, M.A. (2011). The relevance of strategic Management Theory and Research for Supply Chain Management. Journal of Supply Chain Management, 47(1), 9-13. https://doi.org/10.1111/j.1745-493X.2010.03210.x 
Hofer, C.W. (1975). Toward a contigency theory of business strategy. Academy of Management Journal, 18, 784-810. https://doi.org/10.5465/255379

Hofmann, E. (2010). Linking corporate strategy and supply chain management. International Journal of Physical Distribution \& Logistics Management, 40(4), 256-276. https:/ / doi.org/10.1108/09600031011045299

Huang, S.H., Uppal, M., \& Shi, J. (2002). A product driven approach to manufacuring supply chain selection. Supply Chain Management, 7(4), 189-199. https://doi.org/10.1108/13598540210438935

Jemison, D. (1981). The importance of an integrative approach to strategic management. Academy of Management Review, 6, 601-608. https://doi.org/10.5465/amr.1981.4285702

Kathuria, R., Joshi, M.P., \& Porth, S.J. (2007). Organizational alignment and performance: past, present and future. Management Decision, 45(3), 503-517. https://doi.org/10.1108/00251740710745106

Kim, S.W. (2006). Effects of supply chain management practices, integration and competition capability on performance. Supply Chain Management: An International Journal, 11(3), 241-248.

https://doi.org/10.1108/13598540610662149

Kusmantini, T. (2006). Analisis misfit score strategi manufaktur dengan tipe proses produksi dan dampaknya pada kinerja manufaktur pada UKM logam di Pulau Jawa. Jurnal Siasat Bisnis, Universitas Islam Indonesia (Accredited), 12(2), 18-29.

Kusmantini, T. (2007). Analisis misfit score internal fit dan eksternal fit strategi operasi serta dampaknya pada kinerja UKM Logam di Ceper Klaten dan Tegal. Usahawan, XXVII, 37-51.

Marsilac, E., \& Roh, J.J., (2014). Connecting product design, process and supply chain decision to strengthen global supply chain capabilities. International Journal of Production Economics, 147(1), 317-329.

https://doi.org/10.1016/j.ijpe.2013.04.011

Magutu, P.O., Aduda, J., \& Nyoga, R.B., (2015). Does supply chain technology moderate the relationship between SCS and performance? Evidence from large-scale manufacturing firm in Kenya. International Strategic Management Review, 3(1-20), 43-65. https://doi.org/10.1016/j.ism.2015.07.002

McKone-Sweet, K., \& Lee, Y.T. (2009). Development and Analysis of Supply Chain Strategy Taxonomy. Journal of Supply Chain Management, 45(3), 3-24.Meyer, A.D., Tsui, A.S., \& Hinings, C.R. (1993). Configurational approaches to organizational analysis. Academy of Management Journal, 36(6), 1175-1195.

Nakano, M. (2015). Exploratory analysis on the relationship between strategy and structure/process in supply chain. The International Journal of Logistic Management. 26(2), 381-400. https://doi.org/10.1108/IJLM-04-2014-0056

Narasimhan, R., \& Jayaram, J. (1998). Causal Linkages in Supply Chain Management: An Exploratory Study of North American Manufacturing Firms. Decision Sciences, 29(3), 579-605. https://doi.org/10.1111/j.15405915.1998.tb01355.x

Porter, M.E. (1980). Competitive Strategy: Techniques for Analyzing Industries and Competitors. New York: The Free Press.

Porter, M.E. (1981). The contributions of industrial organization to strategic management. Academy of Management Review, 6(6), 609-620.

Priyono, B.S. (2004). Pengaruh Derajat Kesesuaian Hubungan Strategi, Struktur, Karir dan Budaya Organisasi Terhadap Kinerja Perusahaan (Unpublished Dissertation). Universitas Gadjah Mada, Indonesia.

Riyanto, B.L.S. (1999). The Effect of Attitude, Strategy and Decentralization on The Effectiveness of Budget Participation. Journal Riset Akuntansi Indonesia, 2(2), 136-153.

Sambultawee, K. \& Boon-itt, S. (2017). Marketing operation alignment: a systematic literature and citation network analysis review. Kasetsart Journal of Social Science, December, 1-10.

Schandel, D.E., \& Hofer, C.W. (1979). Strategic Management: A new view of business policy and planning. Boston: Little/Brown. 
Shavarini, S.K., \& Salimian, H. (2013). Operations strategy and business strategy alignment model (case of Iranian industries). International Journal of Operations \& Production Management, 33(9), 1108-1130.

https://doi.org/10.1108/IJOPM-12-2011-0467

Simchi-Levi, D., Simchi-Levi, E., \& Kaminsky, P. (1999). Designing and managing the supply chain: Concepts, strategies, and cases. New York: McGrawHill.

Skinner, W. (1969). Manufacturing - Missing Link in Corporate Strategy. Harvard Business Review, 47(3), $136-145$.

Sreedevi, R., \& Saranga, H. (2017). Uncertainty and supply chain risk: the moderating role of sc flexibility in risk mitigation. International Journal of Production Economic, 193(11), 332-342. https://doi.org/10.1016/j.ijpe.2017.07.024

Stonebraker, P.W., \& Liao, J. (2004). Envrionmental turbulence, strategic orientation: Modeling supply chain integration. International Journal of Operations \& Production Management, 24(10), 0144-0577.

https://doi.org/10.1108/01443570410558067

Sum, C., Kow, L.S., \& Chen, C.S. (2004). A taxonomy of operations strategies of high performing small and medium enterprises in Singap. International Journal of Operations \& Production Management, 24(3/4), 321-345. https://doi.org/10.1108/01443570410519051

Swink, M., Narasimhan, R., \& Kim, S.W. (2005). Linking Practice to Performance Empirical Study of High Performing. Production and Inventory Management Journal, 6, 1-10.

Tamas, M. (2000). Mismatched strategies: the weak link in the supply chain? International Journal of Supply Chain Management, 5(4), 171-175. https://doi.org/10.1108/13598540010347280

Tan, J., \& Tan, D. (2005). Environment - Strategy Co-Evaluation and Co-Alignment: A Staged Model of Chinese SOEs Under Transition. Strategic Management Journal, 26, 141-157. https://doi.org/10.1002/smj.437

Tolonen, A., Haapasalo, H., Harkonen, J., \& Verrollot, J. (2017). Supply chain capability creation - the creation of the supply chain readiness for a new product during product development process. International Journal of Production Economics, 194(12), 237-245. https:/ / doi.org/10.1016/j.ijpe.2017.09.007

Van de Ven, A.H., \& Drazin, R. (1985). The Concept of Fit Contigency Theory, Research in Organizational Behavior. Greenwich: JAI Press.

Venkatraman, N. (1989). The concept of fit in strategy research: toward verbal and statistical correspondence. Academy of Management Review, 14, 423-444.

Venkatraman, J., \& Camillus, J.C. (1984). Exploring the concept of "fit" in strategic management. The Academy of Management Review, 9(3), 513-525.

Womack, J.P., Jones, D.T., \& Roos, D. (1990). The Machine that Changed the World. New York: Lawson Associates.

Yinan, Q., Baofeng, H., Zheqiang, W., \& Hoi, Y.J.Y. (2017). The impact of operation and supply chain strategies on integration and performance. International Journal of Production Economics. 185(03), 162-174.

Zhao, X., Sum, C., Qi, Y., Zhang, H., \& Lee, T.S. (2006). A taxonomy of manufacturing strategies in China. Journal of Operations Management, 24, 621-636. https://doi.org/10.1016/j.jom.2005.07.003

Journal of Industrial Engineering and Management, 2018 (www.jiem.org)

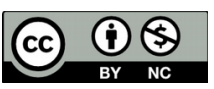

Article's contents are provided on an Attribution-Non Commercial 4.0 Creative commons International License. Readers are allowed to copy, distribute and communicate article's contents, provided the author's and Journal of Industrial Engineering and Management's names are included. It must not be used for commercial purposes. To see the complete license contents, please visit https://creativecommons.org/licenses/by-nc/4.0/. 